\title{
SARS-CoV-2 Seroprevalence in three Kenyan Health and Demographic Surveillance Sites, December 2020-May 2021
}

\section{Authors}

Anthony O. Etyang ${ }^{1 \pm}$, Ifedayo Adetifa ${ }^{1,2 \pm}$, Richard Omore ${ }^{3}$, Thomas Misore ${ }^{3}$, Abdhalah K. Ziraba ${ }^{4}$, Maurine A. Ng'oda ${ }^{4}$, Evelyn Gitau ${ }^{4}$, John Gitonga ${ }^{1}$, Daisy Mugo ${ }^{1}$, Bernadette Kutima ${ }^{1}$, Henry Karanja ${ }^{1}$, Monica Toroitich ${ }^{1}$, James Nyagwange ${ }^{1}$, James Tuju ${ }^{1}$, Perpetual Wanjiku ${ }^{1}$,Rashid Aman ${ }^{5}$, Patrick Amoth ${ }^{5}$, Mercy Mwangangi ${ }^{5}$, Kadondi Kasera ${ }^{5}$, Wangari Ng'ang' ${ }^{6}{ }^{6}$, Donald Akech ${ }^{1}$, Antipa Sigilai ${ }^{1}$, Boniface Karia ${ }^{1}$, Angela Karani ${ }^{1}$, Shirine Voller ${ }^{1,2}$, Charles N. Agoti ${ }^{1}$, Lynette I. Ochola-Oyier ${ }^{1}$, Mark Otiende ${ }^{1}$, Christian Bottomley ${ }^{1}$, Amek Nyaguara ${ }^{1}$, Sophie Uyoga ${ }^{1}$, Katherine Gallagher ${ }^{1}$, Eunice W. Kagucia ${ }^{1}$, Dickens Onyango ${ }^{7}$, Benjamin Tsofa ${ }^{1}$, Joseph Mwangangi ${ }^{1}$, Eric Maitha ${ }^{8}$, Edwine Barasa $^{9,10}$, Philip Bejon ${ }^{1,10}$, George M. Warimwe ${ }^{1,10 \pm}$, J Anthony G Scott ${ }^{1,2 \pm}$, Ambrose Agweyu $^{1 \pm}$

\section{Author Affiliations}

${ }^{1}$ KEMRI-Wellcome Trust Research Programme, Kilifi, Kenya

${ }^{2}$ London School of Hygiene and Tropical Medicine, UK

${ }^{3}$ Kenya Medical Research Institute Centre for Global Health Research, Kisumu, Kenya

${ }^{4}$ African Population and Health Research Center, Nairobi, Kenya

${ }^{5}$ Ministry of Health, Nairobi, Kenya

${ }^{6}$ Presidential Policy and Strategy Unit, The Presidency, Government of Kenya

${ }^{7}$ Department of Health, Kisumu County, Kenya

${ }^{8}$ Department of Health, Kilifi County, Kenya

${ }^{9}$ Health Economics Research Unit, KEMRI-Wellcome Trust Research Programme, Nairobi, Kenya

${ }^{10}$ Centre for Tropical Medicine and Global Health, Nuffield Department of Medicine, Oxford University, UK

Word count:

Abstract: 253

Main text: 2,221

Complete manuscript including tables and references: 4,960

Tables: 2; Figures: 1 
medRxiv preprint doi: https://doi.org/10.1101/2022.02.07.22270012; this version posted February 9, 2022. The copyright holder for this preprint (which was not certified by peer review) is the author/funder, who has granted medRxiv a license to display the preprint in perpetuity. It is made available under a CC-BY 4.0 International license .

Additional Material: Supplementary methods; Supplementary Tables: 2; Supplementary Figures: 1

Corresponding author: Anthony O. Etyang, 813, Mbuyuni Bldg, P.O. Box 230-80108, Kilifi, Kenya

Tel +254730163000

Fax +254417522390

Email: Aetyang@kemri-wellcome.org

${ }^{ \pm}$Equal contribution

Short Title: Serosurveillance for SARS-CoV-2 in population-based samples in Kenya

Key words: SARS-CoV-2, serosurveillance, Kenya, Health and Demographic Surveillance System 


\section{ABSTRACT}

\section{Background}

Most of the studies that have informed the public health response to the COVID-19 pandemic in Kenya have relied on samples that are not representative of the general population. We conducted population-based serosurveys at three Health and Demographic Surveillance Systems (HDSSs) to determine the cumulative incidence of infection with SARS-CoV-2.

\section{Methods}

We selected random age-stratified population-based samples at HDSSs in Kisumu, Nairobi and Kilifi, in Kenya. Blood samples were collected from participants between 01 Dec 2020 and 27 May 2021. No participant had received a COVID-19 vaccine. We tested for IgG antibodies to SARS-CoV-2 spike protein using ELISA. Locallyvalidated assay sensitivity and specificity were 93\% (95\% Cl 88-96\%) and 99\% (95\% Cl 98-99.5\%), respectively. We adjusted prevalence estimates using classical methods and Bayesian modelling to account for the sampling scheme and assay performance.

\section{Results}

We recruited 2,559 individuals from the three HDSS sites, median age (IQR) 27 (1078) years and $52 \%$ were female. Seroprevalence at all three sites rose steadily during the study period. In Kisumu, Nairobi and Kilifi, seroprevalences (95\% Cl) at the beginning of the study were $36.0 \%$ (28.2-44.4\%), 32.4\% (23.1-42.4\%), and $14.5 \%(9.1-21 \%)$, and respectively; at the end they were $42.0 \%(34.7-50.0 \%), 50.2 \%$ (39.7-61.1\%), and $24.7 \%(17.5-32.6 \%)$, respectively. Seroprevalence was substantially lower among children ( $<16$ years) than among adults at all three sites $(p \leq 0.001)$. 
medRxiv preprint doi: https://doi.org/10.1101/2022.02.07.22270012; this version posted February 9,2022 . The copyright holder for this preprint (which was not certified by peer review) is the author/funder, who has granted medRxiv a license to display the preprint in perpetuity.

It is made available under a CC-BY 4.0 International license.

\section{Conclusion}

By May 2021 in three broadly representative populations of unvaccinated individuals

in Kenya, seroprevalence of anti-SARS-CoV-2 IgG was 25-50\%. There was wide variation in cumulative incidence by location and age. 
medRxiv preprint doi: https://doi.org/10.1101/2022.02.07.22270012; this version posted February 9, 2022. The copyright holder for this preprint

\section{INTRODUCTION}

Kenya has had five waves of SARS-CoV-2 infection as of January 2022. As of 31

December 2021 the official number of reported cases and deaths was 295,028 and

5,378 respectively. ${ }^{1}$ The official number of reported cases is widely acknowledged to be an underestimate of the true number of infections. Accurate estimates of the proportion of the population previously infected with SARS-CoV-2 are important to understand the epidemiology of the infection and inform control strategies such as vaccination and non-pharmaceutical interventions. Previous studies have shown significant temporal and spatial heterogeneity in the pattern of infections in Kenya, ${ }^{2-6}$ but these studies had the limitation of not being population-based, instead relying on convenience samples of special population groups such as blood donors, ${ }^{2,6}$ antenatal clinic (ANC) attendees, ${ }^{5}$ truck drivers ${ }^{4}$ and health care workers $(\mathrm{HCW}) .{ }^{3} \mathrm{~A}$ similar situation obtains in many low and middle income countries (LMICs), with only a handful of published population based studies having been conducted in Africa, ${ }^{7-11}$ which is home to over one billion people.

Sub-Saharan Africa appears to have had lower mortality from SARS-CoV-2 infections than other parts of the world. One reason that has been proposed for this is that the African population is generally younger. ${ }^{12}$ To test this hypothesis, accurate age specific estimates of cumulative incidence of infection are required from population-based studies. These estimates can then be used to determine agespecific infection fatality rates. However, previous studies have been susceptible to several biases, including the absence of children in studies of blood donors, the restriction of ANC studies to females, and potentially higher exposure to SARS-CoV2 among HCWs and truck drivers. In addition, many of these studies have over- 
sampled urban residents, yet majority of the people in sub-Saharan Africa live in rural areas.

We report results from the first round of a population-based survey for presence of SARS-CoV-2 antibodies at three ${ }^{13-15}$ health and demographic surveillance sites broadly representative of the population of Kenya.

\section{METHODS}

\section{Study sites and Participants}

Following consultations with the Ministry of Health, three representative health and demographic surveillance systems (HDSS's) spread across Kenya were chosen as sites for the serosurveillance study. The sites were as follows: Manyatta HDSS in Kisumu (Western Kenya), ${ }^{13}$ Nairobi urban HDSS (Central Kenya), ${ }^{14}$ and Kilifi HDSS, ${ }^{15}$ (South East Kenya) (Supplementary Figure 1). The total population under regular surveillance at the three sites is $\sim 470,000$. $^{13-15}$

The Kisumu HDSS comprises a semi-urban population. ${ }^{13}$ At the median date of sample collection in Kisumu (31 March 2021), the official number of reported cases of SARS-CoV-2 infection in the county was 2,670 , and the official number of reported COVID-19 deaths was 24 .

The Nairobi HDSS comprises an urban population. ${ }^{14}$ At the median date of sample collection in Nairobi (28 March 2021), the official number of reported cases of SARSCoV-2 infection in the county was 60,836 , and the official number of reported COVID-19 deaths was 984. 
medRxiv preprint doi: https://doi.org/10.1101/2022.02.07.22270012; this version posted February 9, 2022. The copyright holder for this preprint (which was not certified by peer review) is the author/funder, who has granted medRxiv a license to display the preprint in perpetuity.

It is made available under a CC-BY 4.0 International license.

The Kilifi HDSS comprises a predominantly rural population. ${ }^{15}$ At the median date of sample collection in Kilifi (17 Feb 2021), the official number of reported cases of SARS-CoV-2 infection in the county was 2,613 , and the official number of reported COVID-19 deaths was 21.

At each of the three sites, we randomly selected an age-stratified sample of 50 individuals in each 5-year age band from 15-65+ years and above, and 100 in each 5-year age band from 0-14 years. A sample of 300 participants $<15$ years old would suffice to estimate seroprevalence of $1 \%$ with a $2 \%$ margin of error, and a sample of 550 participants aged $\geq 15$ years would suffice to estimate seroprevalence of $3-5 \%$ with a $<5 \%$ error margin.

Participants were selected from population lists of residents at the HDSS sites, which in the pre-pandemic period were updated at least twice a year. Surveillance activities at all sites were temporarily halted from March to September 2020 because of the disruption caused by the pandemic. Following approval from regulatory authorities and the Ministry of Health fieldwork activities resumed prior to the serosurvey, as this was deemed an essential public health activity.

Inclusion criteria for the study were that the individual should be a resident of the HDSS and provide consent. Potential participants were excluded if they had a bleeding disorder or other medical contraindication for venipuncture.

Members of the study team visited the homes of selected participants between 01 December 2020 and 27 May 2021. Potential participants that could not be found after three attempts were replaced by randomly selected individuals meeting the same age and sex category as the originally selected individual. 


\section{Ethics and Consents}

Ethical approval for conducting the study and publication of these data was obtained from the Kenya Medical Research Institute Scientific and Ethics Review Unit (KEMRI/SERU/CGMR-C/203/4085). Written informed consent (and assent where applicable) was obtained from all participants, or their guardians before their participation in the study.

\section{Study procedures}

Study staff administered a questionnaire to the participants either electronically or on paper, to collect data on demographic and clinical characteristics, including whether the individual had experienced symptoms compatible with COVID-19 in the preceding six months. None of the study participants had received any dose of a COVID-19 vaccine at the time of sample collection.

They then collected $5 \mathrm{ml}$ ( $2 \mathrm{ml}$ in children under 5 years) of venous blood from each participant. Serum was obtained by centrifuging the samples at $450 \times \mathrm{g}$ for 5 minutes. Serum samples were then stored in $-80^{\circ} \mathrm{C}$ freezers at the study sites before being transported in dry ice to the KEMRI-Wellcome Trust research laboratories in Kilifi for assays.

\section{ELISA for SARS-CoV-2 Spike Protein}

All samples were tested at the KEMRI-Wellcome Trust Research Programme laboratories in Kilifi for IgG to SARS-CoV-2 whole spike protein using an adaptation of the Krammer Enzyme Linked Immunosorbent Assay (ELISA). ${ }^{16}$ Validation of the assay was described previously. ${ }^{6}$ Briefly, sensitivity, estimated in 174 SARS-CoV-2 PCR positive Kenyan adults in Nairobi and a panel of sera from the UK National 
Institute of Biological Standards and Control (NIBSC), was 92.7\% (95\% Cl 87.9-

96.1\%); specificity, estimated in 910 serum samples from Kenya drawn in 2018 (i.e. pre-pandemic period), was $99.0 \%$ (95\% Cl 98.1-99.5). Results were expressed as the ratio of test OD to the OD of the plate negative control; samples with OD ratios greater than two were considered positive for SARS-CoV-2 IgG.

\section{Statistical Analyses}

In the primary analysis, we estimated seroprevalence at each site based on the weighted proportion of samples with an OD ratio $>2$. The study period was divided into six 30-day periods and separate seroprevalence estimates were computed for each period. For site specific age-stratified analyses, we used three time periods of 60 days each. We adjusted the seroprevalence estimates for assay sensitivity and specificity using both classical ${ }^{17}$ and Bayesian modelling ${ }^{18}$. Summary estimates for each site were weighted to account for underlying population, age, and sex structure at the study sites. In the Bayesian modelling, non-informative priors were used for all parameters, and the models were fitted using the Rstan software package ${ }^{19}$, as with previous studies. ${ }^{3,6}$ We tested whether seropositivity was associated with sex, age, or period of sample collection using multivariable logistic regression.

All analyses were conducted using Stata ${ }^{\mathrm{TM}}$ Version 15 software (College Station, Texas, USA) and R version 3.6.1 (Vienna, Austria). 


\section{RESULTS}

We recruited 2,559 individuals from the three health and demographic surveillance sites (Figure 1). Samples were collected from 08 Feb 2021 to 27 May 2021 (median sample date 31 Mar 2021) in Kisumu, 21 Jan 2021 to 17 May 2021 (median sample date 28 Mar 2021) in Nairobi, and 01 Dec 2020 to 28 April 2021 (median sample date 17 Feb 2021) in Kilifi. The median age (IQR, range) of study participants was 27 years $(10-78,0-100)$ and $52 \%$ were female.

Table 1 displays Bayesian adjusted seroprevalence estimates at the three sites for each month between December 2020 and May 2021. In Kisumu seroprevalence was $36.0 \%$ (95 Cl 28.2-44.4\%) in February 2021 rising to $42.0 \%$ (95\% Cl 34.7-50.0\%) in May 2021. In Nairobi, seroprevalence was 32.4\% (95\% Cl 23.1-42.4\%) in January 2021 rising to $50.2 \%$ (95\% Cl 39.7-61.1\%) in May 2021. Seroprevalence in Kilifi rose substantially during the study period, starting at $14.5 \%(95 \% \mathrm{Cl} 9.1-21 \%)$ in December 2020, rising to $24.7 \%(95 \% \mathrm{Cl} 17.5-32.6 \%)$ in April 2021. The temporal differences in seroprevalence were statistically significant in the multivariable logistic regression models in Kilifi $(p=0.017)$ and Nairobi $(p=0.012)$ but not in Kisumu $(\mathrm{p}=0.172)$.

Overall, seroprevalence in males $(32.7 \%, 95 \% \mathrm{Cl} 29.6-36 \%)$ did not differ significantly from seroprevalence in females (33.8\%, 95\% Cl 30.8-37.2\%). Significant sex differences were not apparent in site specific analyses (Supplementary Table S1).

Table 2 displays Bayesian adjusted age specific seroprevalence at each of the three sites over three 60-day intervals. Variation in seroprevalence with age was significant at each of the three sites $(P=0.002$ in Kisumu and $P<0.001$ Nairobi and 
Kilifi) and the pattern of variation was similar at each site. Across the whole study period seroprevalence was substantially lower among children aged $<16$ years than among older individuals at each site. In Kisumu seroprevalence in individuals aged $<16$ years and $\geq 16$ years was $29.1 \%(95 \% \mathrm{Cl} 23.7-35 \%)$ and $43.8 \%(95 \% \mathrm{Cl} 39.1-$ $49 \%)$, respectively; in Nairobi, it was $29.1 \%(95 \% \mathrm{Cl} 23.7-35 \%)$ and $47.6 \%(95 \% \mathrm{Cl}$ 42.6-52.8\%), respectively; in Kilifi it was $14.5 \%$ (95\% Cl 10.4-19.2\%) and $25.1 \%$ (95\% Cl 21.1-29.3\%), respectively.

Results of analyses where we used classical methods to adjust for assay sensitivity and specificity were essentially similar to the Bayesian adjusted estimates (Tables S1 and S2). 
medRxiv preprint doi: https://doi.org/10.1101/2022.02.07.22270012; this version posted February 9, 2022. The copyright holder for this preprint (which was not certified by peer review) is the author/funder, who has granted medRxiv a license to display the preprint in perpetuity.

It is made available under a CC-BY 4.0 International license .

\section{DISCUSSION}

In this population-based serosurveillance study using a locally-validated assay at three sites broadly representative of Kenya, we found that $25-50 \%$ of the resident populations had SARS-CoV-2 antibodies by the end of our study in May 2021. As none of the study participants had received a COVID-19 vaccine the presence of anti-spike antibodies indicates previous infection. There were large temporal, agerelated and geographical differences in seroprevalence; in particular, older individuals and those in the urban areas of Kisumu and Nairobi had higher seroprevalence.

Our results are generally consistent with other community surveys conducted in Kenya at a roughly similar time point during the pandemic. In two household surveys conducted in Nairobi in November-December 2020, overall seroprevalence was $34.7 \%$ and $43.3 \%,{ }^{10,20}$ where we found a seroprevalence of $32.4 \%$ in Nairobi in January 2021; we observed similar age related seroprevalence patterns compared to the previous surveys.

Our results from this population-based survey were also generally consistent with those obtained from special population groups in Kenya. This provides assurance that previous studies among other populations in Kenya have been broadly representative of seroprevalence trends. For example, seroprevalence among health care workers in Nairobi from July to December 2020 was $44 \%,{ }^{3}$ compared to $32 \%$ in the general population of the Nairobi HDSS in January 2021. Seroprevalence among blood donors in the counties in which Kisumu, Nairobi, and Kilifi are located were $38 \%, 62 \%$ and $43 \%$ respectively in January to March $2021^{21}$, compared to $40 \%$, 47\% and 25\% during March 2021 in the present study (Table 1). Of note studies of 
blood transfusion donors are restricted to individuals aged 16-65 years who have substantially higher seroprevalence than children or older adults in our study. Seroprevalence estimates from other population samples showed geographical variations of similar magnitude to those observed in the present study. Comparisons between different sampling methods are highly susceptible to confounding as illustrated above.

A significant strength of this study is the random sampling of a defined population. The results are therefore more generalizable to the Kenyan population than previous studies that involved special populations. ${ }^{2-6}$ Although there had been two other population-based studies ${ }^{10,20}$ conducted earlier, both were limited to Nairobi, the capital city of Kenya. Our inclusion of other sites in this study, far removed from Nairobi, helps to provide broader insights into the extent of the SARS-CoV-2 pandemic in Kenya. Another strength is that we used an assay that had been rigorously validated using samples from the local population and reference panels from the National Institute for Biological Standards and Control (NIBSC) in the UK, as well as the $\mathrm{WHO}^{22,23}$

A key limitation of the study is that we were unable to fully account for waning of antibodies, which could have led to an underestimation of seroprevalence. In a previous study, we undertook mixture modelling, ${ }^{24}$ which does not rely on thresholds, but instead assumes that the population sampled consists of two groups with different distributions of antibody levels; this suggested that the threshold-based method was significantly underestimating the true seroprevalence. We were however unable to conduct similar analysis for this dataset, as the mixture modelling requires control data from the respective sites which we did not have. 
An additional limitation was the fact that nearly half of those who were targeted through the random sampling were not present at home. These were in most cases individuals who had gone to their workplaces. Given that these individuals would have had more interactions with others both at the workplace and during commuting, it is likely that the seroprevalence figures presented here are an underestimate of the true value.

In conclusion, in this population-based study at three health and demographic surveillance sites, broadly representative of the population in Kenya, we found that between a quarter and a half of the population had evidence of previous infection by May 2021, though with marked variation in infection risk by age and geographical region. 
medRxiv preprint doi: https://doi.org/10.1101/2022.02.07.22270012; this version posted February 9, 2022. The copyright holder for this preprint (which was not certified by peer review) is the author/funder, who has granted medRxiv a license to display the preprint in perpetuity.

It is made available under a CC-BY 4.0 International license .

\section{Funding}

This project was funded by the Wellcome Trust (grants 220991/Z/20/Z and 203077/Z/16/Z), the Bill and Melinda Gates Foundation (INV-017547), and the Foreign Commonwealth and Development Office (FCDO) through the East Africa Research Fund (EARF/ITT/039) and is part of an integrated programme of SARSCoV-2 sero-surveillance in Kenya led by KEMRI Wellcome Trust Research Programme.

A.A. is funded by a DFID/MRC/NIHR/Wellcome Trust Joint Global Health Trials Award (MR/R006083/1), J.A.G.S. is funded by a Wellcome Trust Senior Research Fellowship (214320) and the NIHR Health Protection Research Unit in Immunisation, I.M.O.A. is funded by the United Kingdom's Medical Research Council and Department For International Development through an African Research Leader Fellowship (MR/S005293/1) and by the NIHR-MPRU at UCL (grant 2268427 LSHTM). G.M.W. is supported by a fellowship from the Oak Foundation. C.N.A. is funded by the DELTAS Africa Initiative [DEL-15-003], and the Foreign, Commonwealth and Development Office and Wellcome (220985/Z/20/Z). S.U. is funded by DELTAS Africa Initiative [DEL-15-003], L.I.O.-O. is funded by a Wellcome Trust Intermediate Fellowship (107568/Z/15/Z). R.A is funded by National Institute for Health Research (NIHR) (project reference 17/63/82) using UK aid from the UK Government to support global health research.

The views expressed in this publication are those of the authors and not necessarily those of the funding agencies

\section{Conflict of Interest}

All authors: No reported conflicts. 
medRxiv preprint doi: https://doi.org/10.1101/2022.02.07.22270012; this version posted February 9, 2022. The copyright holder for this preprint (which was not certified by peer review) is the author/funder, who has granted medRxiv a license to display the preprint in perpetuity.

\section{Acknowledgements}

We thank Nelson Mbaya, Salma Musa, Boniface Ingumba Butichi and Nicholas Kiprono Mutai for their roles in data, laboratory and field work management in Nairobi. We thank Victor Akelo, Beth A. Tippet Barr, Dickson Gethi, Kephas Otieno and Frederick Oluoch for their technical support before and during implementation of the study in Kisumu. We thank F. Krammer for providing the plasmids used to generate the spike protein used in this work. Development of SARS-CoV-2 reagents was partially supported by the NIAID Centres of Excellence for Influenza Research and Surveillance (CEIRS) contract HHSN272201400008C. The COVID-19 convalescent plasma panel (NIBSC 20/118) and research reagent for SARS-CoV-2 Ab (NIBSC 20/130) were obtained from the NIBSC, UK. We also thank the WHO SOLIDARITY II network for sharing of protocols and for facilitating the development and distribution of control reagents. This paper has been published with the permission of the director, Kenya Medical Research Institute.

For the purpose of Open Access, the author has applied a CC-BY public copyright licence to any author accepted manuscript version arising from this submission. 
medRxiv preprint doi: https://doi.org/10.1101/2022.02.07.22270012; this version posted February 9, 2022. The copyright holder for this preprint (which was not certified by peer review) is the author/funder, who has granted medRxiv a license to display the preprint in perpetuity.

It is made available under a CC-BY 4.0 International license.

\section{REFERENCES}

1. COVID-19 situation reports. (Accessed 02 January 2022, at

https://www.health.go.ke/\#1591180376422-52af4c1e-256b.)

2. Adetifa IMO, Uyoga S, Gitonga JN, et al. Temporal trends of SARS-CoV-2 seroprevalence during the first wave of the COVID-19 epidemic in Kenya. Nature Communications 2021;12:1-6.

3. Etyang AO, Lucinde R, Karanja H, et al. Seroprevalence of Antibodies to Severe Acute Respiratory Syndrome Coronavirus 2 Among Healthcare Workers in Kenya. Clin Infect Dis 2022;74:288-93.

4. Kagucia EW, Gitonga JN, Kalu C, et al. Anti-Severe Acute Respiratory Syndrome Coronavirus 2 Immunoglobulin G Antibody Seroprevalence among Truck Drivers and Assistants in Kenya. Open Forum Infectious Diseases 2021;8:2-5.

5. Lucinde R, Mugo D, Bottomley C, et al. Sero-surveillance for IgG to SARS-CoV-2 at antenatal care clinics in two Kenyan referral hospitals. medRxiv 2021:2021.02.05.21250735.

6. Uyoga S, Adetifa IMO, Karanja HK, et al. Seroprevalence of anti-SARS-CoV-2 IgG antibodies in Kenyan blood donors. Science 2020:eabe1916-eabe.

7. Wiens KE, Mawien PN, Rumunu J, et al. Seroprevalence of severe acute respiratory syndrome coronavirus 2 IgG in Juba, South Sudan, 2020. Emerg Infect Dis 2021;27:1598-606.

8. Fryatt A, Simms V, Bandason T, et al. Community SARS-CoV-2 seroprevalence before and after the second wave of SARS-CoV-2 infection in Harare, Zimbabwe. EClinicalMedicine $2021 ; 41: 101172$.

9. Wolter N, Tempia S, Von Gottberg A, et al. Seroprevalence of SARS-CoV-2 after the Second Wave in South Africa in HIV-Infected and Uninfected Persons: A Cross-Sectional Household Survey, November 2020 - April 2021. SSRN Electronic Journal 2021;11:204-17.

10. Munywoki PK, Nasimiyu C, Alando MD, et al. Seroprevalence and risk factors of SARS-CoV2 infection in an urban informal settlement in Nairobi, Kenya, December 2020. F1000Research 2021;10:853-.

11. Gudina EK, Ali S, Girma E, et al. Seroepidemiology and model-based prediction of SARSCoV-2 in Ethiopia: longitudinal cohort study among front-line hospital workers and communities. The Lancet Global Health 2021;9:e1517-e27.

12. Maeda JM, Nkengasong JN. The puzzle of the COVID-19 pandemic in Africa. Science 2021;371:27-8.

13. Cunningham SA, Shaikh NI, Nhacolo A, et al. Health and Demographic Surveillance Systems within the Child Health and Mortality Prevention Surveillance Network. Clin Infect Dis 2019;69:S274-

S9.

14. Beguy D, Elung'ata P, Mberu B, et al. Health \& Demographic Surveillance System Profile: The Nairobi Urban Health and Demographic Surveillance System (NUHDSS). Int J Epidemiol 2015;44:462-71.

15. Scott JA, Bauni E, Moisi JC, et al. Profile: The Kilifi Health and Demographic Surveillance System (KHDSS). Int J Epidemiol 2012;41:650-7.

16. Amanat F, Stadlbauer D, Strohmeier S, et al. A serological assay to detect SARS-CoV-2 seroconversion in humans. Nat Med 2020;26:1033-6.

17. Rogan WJ, Gladen B. Estimating prevalence from the results of a screening test. Am J Epidemiol 1978;107:71-6.

18. Gelman A, Carpenter B. Bayesian analysis of tests with unknown specificity and sensitivity. Journal of the Royal Statistical Society Series C: Applied Statistics 2020;69:1269-83.

19. RStan: the R interface to Stan. R package version 2.21. 2, http://mc-stan.org/. 2020.

20. Ngere I, Dawa J, Hunsperger E, et al. High seroprevalence of SARS-CoV-2 but low infection fatality ratio eight months after introduction in Nairobi, Kenya. Int $J$ Infect Dis 2021;112:25-34.

21. Uyoga S, Adetifa IMO, Otiende M, et al. Prevalence of SARS-CoV-2 Antibodies From a National Serosurveillance of Kenyan Blood Donors, January-March 2021. JAMA 2021;326:1436-. 22. Giada Mattiuzzo EMB, Mark Hassall, Stephanie Routley, Samuel Richardson, Valentina Bernasconi, Paul Kristiansen, Heli Harvala, David Roberts, Malcom G Semple , Lance CW Turtle, Peter JM Openshaw and Kenneth Baillie on behalf of the ISARICC Investigators, Lise Sofie Haug Nissen-Meyer, Arne Broch Brantsæter, Helen Baxendale, Eleanor Atkinson, Peter Rigsby, David Padley, Neil Almond, Nicola J. Rose, Mark Page and the collaborative study participants Establishment of the WHO International Standard and Reference Panel for anti-SARS-CoV-2 antibody; 2020. 
medRxiv preprint doi: https://doi.org/10.1101/2022.02.07.22270012; this version posted February 9, 2022. The copyright holder for this preprint (which was not certified by peer review) is the author/funder, who has granted medRxiv a license to display the preprint in perpetuity.

It is made available under a CC-BY 4.0 International license.

23. Nyagwange J, Kutima B, Mwai K, et al. Comparative performance of WANTAI ELISA for total immunoglobulin to receptor binding protein and an ELISA for IgG to spike protein in detecting SARSCoV-2 antibodies in Kenyan populations. J Clin Virol 2022;146:105061-.

24. Bottomley C, Otiende M, Uyoga S, et al. Quantifying previous SARS-CoV-2 infection through mixture modelling of antibody levels. Nature Communications 2021;12:1-7. 
Table 1: Seroprevalence by HDSS site and study period

\begin{tabular}{|c|c|c|c|c|c|c|c|c|c|c|c|c|}
\hline \multirow[b]{4}{*}{ Period } & \multicolumn{12}{|c|}{ HDSS site } \\
\hline & \multicolumn{4}{|c|}{ Kisumu } & \multicolumn{4}{|c|}{ Nairobi } & \multicolumn{4}{|c|}{ Kilifi } \\
\hline & \multirow[b]{2}{*}{$\mathrm{N}$} & \multirow{2}{*}{$\begin{array}{c}\text { Sero- } \\
\text { positive } \\
\mathrm{n}\end{array}$} & \multicolumn{2}{|c|}{$\begin{array}{c}\text { Bayesian } \\
\text { adjustment§ }\end{array}$} & \multirow[b]{2}{*}{$\mathrm{N}$} & \multirow{2}{*}{$\begin{array}{c}\text { Sero- } \\
\text { positive } \\
\mathrm{n}\end{array}$} & \multicolumn{2}{|c|}{$\begin{array}{c}\text { Bayesian } \\
\text { adjustment§ }\end{array}$} & \multirow[b]{2}{*}{$\mathrm{N}$} & \multirow{2}{*}{$\begin{array}{l}\text { Sero- } \\
\text { positive } \\
n\end{array}$} & \multicolumn{2}{|c|}{$\begin{array}{c}\text { Bayesian } \\
\text { adjustment§ }\end{array}$} \\
\hline & & & $\%$ & $95 \% \mathrm{Cl}$ & & & $\%$ & $95 \% \mathrm{Cl}$ & & & $\%$ & $95 \% \mathrm{Cl}$ \\
\hline 01 Dec 20- 31 Dec 20 & - & - & - & & - & - & - & & 162 & 27 & 14.5 & $9.1-21$ \\
\hline 01 Jan 21- 31 Jan 21 & - & - & - & & 124 & 39 & 32.4 & $23.1-42.4$ & 113 & 23 & 20.9 & $13.4-29.8$ \\
\hline 01 Mar 21-31 Mar 21 & 218 & 81 & 39.9 & $32.3-47.8$ & 186 & 77 & 47.1 & $38.0-56.6$ & 197 & 47 & 24.6 & $17.9-31.7$ \\
\hline 01 Apr 21-30 Apr 21 & 204 & 73 & 36.6 & $28.9-44.5$ & 283 & 104 & 38.0 & $31.1-45.3$ & 145 & 35 & 24.7 & $17.5-32.6$ \\
\hline 01 May 21-31 May 21 & 217 & 85 & 42.0 & $34.7-50.0$ & 113 & 54 & 50.2 & $39.7-61.1$ & - & - & - & \\
\hline 01 Dec $20-31$ May 21 & 853 & 308 & 38.1 & $34.1-42.4$ & 850 & 322 & 40.4 & $36.0-45.0$ & 856 & 173 & 19.8 & 16.8-23.1 \\
\hline
\end{tabular}

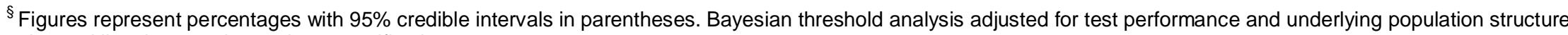
using multilevel regression and poststratification 
Table 2: Age specific seroprevalence at three HDSS sites in Kenya

\begin{tabular}{|c|c|c|c|c|c|c|c|c|c|c|c|c|}
\hline & \multicolumn{12}{|c|}{ Study Period } \\
\hline & \multicolumn{3}{|c|}{01 Dec 2020-29 Jan 2021} & \multicolumn{3}{|c|}{30 Jan 2021-29 Mar2021 } & \multicolumn{3}{|c|}{30 Mar 2021-27 May2021 } & \multicolumn{3}{|c|}{ Overall } \\
\hline & $\mathbf{N}$ & $+\mathrm{VE}$ & Sero-prevalence $^{ \pm}$ & $\mathbf{N}$ & +VE & Sero-prevalence $^{ \pm}$ & $\mathbf{N}$ & $+\mathrm{VE}$ & Sero-prevalence $^{ \pm}$ & $\mathbf{N}$ & +VE & Sero-prevalence $^{ \pm}$ \\
\hline \multicolumn{13}{|l|}{ Kisumu $^{\S}$} \\
\hline$<16$ years & - & - & - & 165 & 40 & $28.9(21.3-38)$ & 144 & 42 & $34.4(26.1-42.4)$ & 309 & 82 & $30.1(24.4-36.3)$ \\
\hline $16-24$ years & - & - & - & 44 & 20 & $44.9(32.9-58.9)$ & 46 & 20 & $43.7(33-56.1)$ & 90 & 40 & $45.2(36.1-55.4)$ \\
\hline 25-34 years & - & - & - & 37 & 18 & $46.4(33.7-61.9)$ & 66 & 20 & $36.4(25.9-46.3)$ & 103 & 38 & $39.7(31.2-48.6)$ \\
\hline $35-44$ years & - & - & - & 53 & 24 & $45.2(33.9-58.5)$ & 47 & 24 & $46.4(35.2-61)$ & 100 & 48 & $47.4(38.1-57.7)$ \\
\hline $45-54$ years & - & - & - & 41 & 15 & $40.0(27.9-52.9)$ & 61 & 27 & $43.6(33.5-55.6)$ & 102 & 42 & $42.6(33.9-52.0)$ \\
\hline $55-64$ years & - & - & - & 48 & 18 & $40.2(28.6-52.9)$ & 51 & 20 & $40.8(30.6-52.4)$ & 99 & 38 & $40.8(32.1-50.1)$ \\
\hline$\geq 65$ years & - & - & - & 29 & 11 & $40.5(27.3-55)$ & 21 & 9 & $42.7(29.9-58.2)$ & 50 & 20 & $42.0(31.1-54.1)$ \\
\hline \multicolumn{13}{|l|}{ Nairobi } \\
\hline$<16$ years & 33 & 8 & $28.4(15.6-42.3)$ & 130 & 30 & $26.5(18.7-35.4)$ & 154 & 45 & $33.7(25.6-42.2)$ & 317 & 83 & $29.1(23.7-35.0)$ \\
\hline $16-24$ years & 8 & 1 & $27.9(9.8-47.5)$ & 41 & 25 & $59.5(44-74.9)$ & 40 & 14 & $41.2(27.9-54.8)$ & 89 & 40 & $47.4(37.4-58.0)$ \\
\hline $25-34$ years & 14 & 2 & $26.1(9.6-43.4)$ & 26 & 8 & 36.7 (20.9-54) & 52 & 23 & $47.5(35.4-60.6)$ & 92 & 33 & $39.8(30.0-49.9)$ \\
\hline $35-44$ years & 6 & 2 & $32.1(13.5-56.7)$ & 38 & 21 & $54.6(39.5-70.6)$ & 57 & 28 & $51.1(38.7-64.2)$ & 101 & 51 & $52.2(42.1-62.6)$ \\
\hline $45-54$ years & 8 & 3 & $32.7(14.9-56.9)$ & 44 & 20 & $46.9(33.1-61.7)$ & 47 & 20 & $46.4(33.7-59.6)$ & 99 & 43 & $46.2(36.5-56.3)$ \\
\hline $55-64$ years & 14 & 5 & $33.0(16.6-54)$ & 44 & 12 & $32.4(19.7-46.1)$ & 43 & 26 & $58.2(42.9-73.5)$ & 101 & 43 & $45.4(35.8-55.3)$ \\
\hline$\geq 65$ years & 12 & 8 & $43.8(23.4-72.5)$ & 25 & 12 & $48.4(31.5-66.6)$ & 14 & 9 & $55.3(37.8-76.5)$ & 51 & 29 & $55.5(42.6-69.3)$ \\
\hline \multicolumn{13}{|l|}{ Kilifi } \\
\hline$<16$ years & 93 & 6 & $9.8(4-17.3)$ & 142 & 17 & $15.7(9.5-22.2)$ & 74 & 17 & $25.0(15.8-35.1)$ & 309 & 40 & $14.5(10.4-19.2)$ \\
\hline $16-24$ years & 29 & 5 & $18.9(8.5-32.3)$ & 43 & 12 & $24.8(16.1-37.1)$ & 21 & 3 & $21.8(8.4-36.5)$ & 93 & 20 & $22.5(15.1-31.0)$ \\
\hline 25-34 years & 28 & 5 & $19.3(8.8-33)$ & 53 & 13 & $23.5(15.4-34.1)$ & 20 & 3 & $22.2(8.6-37.2)$ & 101 & 21 & $22.0(15.0-30.0)$ \\
\hline $35-44$ years & 31 & 7 & $22.3(11.2-37)$ & 49 & 14 & $25.4(16.6-37.8)$ & 21 & 12 & $43.5(23.9-67.7)$ & 101 & 33 & $31.4(22.6-41.6)$ \\
\hline $45-54$ years & 28 & 10 & $30.5(16.5-48.4)$ & 59 & 11 & $20.5(12.9-29.3)$ & 13 & 4 & $29.3(13.9-49.7)$ & 100 & 25 & $25.2(17.7-33.8)$ \\
\hline $55-64$ years & 41 & 7 & $18.5(9.1-30.3)$ & 51 & 10 & $21.0(12.9-30.4)$ & 9 & 2 & $26.4(10.2-47)$ & 101 & 19 & $20.5(13.6-28.1)$ \\
\hline$\geq 65$ years & 22 & 8 & $29.8(15.2-49.2)$ & 24 & 6 & $23.0(13.5-36.1)$ & 5 & 1 & $26.3(8.8-48.7)$ & 51 & 15 & $27.3(17.8-39.4)$ \\
\hline
\end{tabular}

${ }^{ \pm}$Performance adjusted Bayesian threshold analysis adjusted for test performance and underlying population structure using multilevel regression and poststratification.

Figures represent percentages with $95 \%$ credible intervals in parentheses.

$\S$ Kisumu data were collected from 01 Feb 2021-27 May 2021 
Figure 1: Study Flow chart

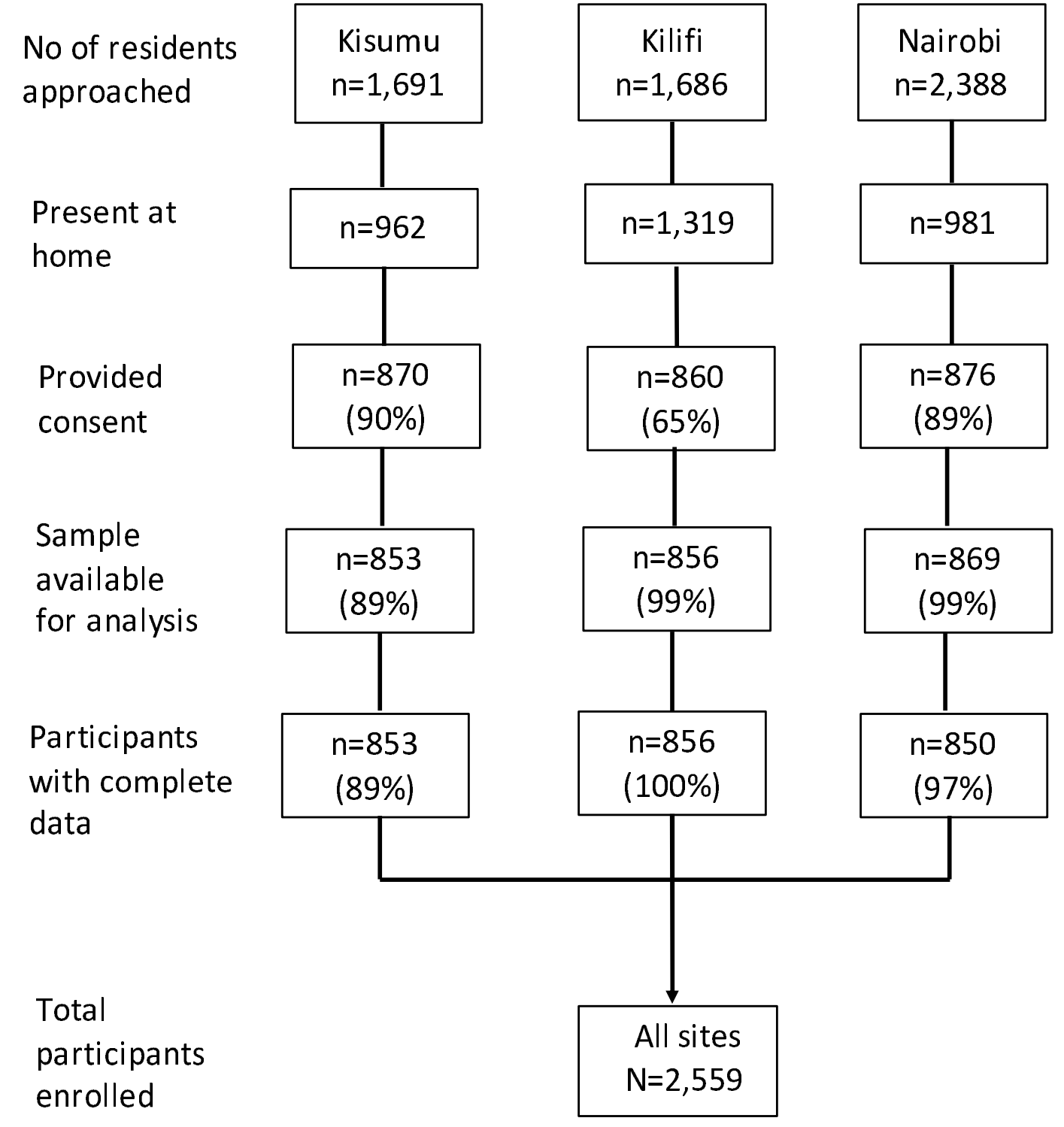




\section{Supplementary Appendix}

\section{SARS-CoV-2 Seroprevalence in three Kenyan Health and Demographic Surveillance Sites, December 2020-May 2021}

\section{Authors}

Anthony O. Etyang ${ }^{1 \pm}$, Ifedayo Adetifa ${ }^{1,2 \pm}$, Richard Omore ${ }^{3}$, Thomas Misore ${ }^{3}$, Abdhalah K. Ziraba ${ }^{4}$, Maurine A. Ng'oda ${ }^{4}$, Evelyn Gitau ${ }^{4}$, John Gitonga ${ }^{1}$, Daisy Mugo ${ }^{1}$, Bernadette Kutima ${ }^{1}$, Henry Karanja ${ }^{1}$, Monica Toroitich ${ }^{1}$, James Nyagwange ${ }^{1}$, James Tuju ${ }^{1}$, Perpetual Wanjiku ${ }^{1}$,Rashid Aman ${ }^{5}$, Patrick Amoth ${ }^{5}$, Mercy Mwangangi ${ }^{5}$, Kadondi Kasera ${ }^{5}$, Wangari Ng'ang' ${ }^{6}{ }^{6}$, Donald Akech ${ }^{1}$, Antipa Sigilai ${ }^{1}$, Boniface Karia ${ }^{1}$, Angela Karani ${ }^{1}$, Shirine Voller ${ }^{1,2}$, Charles N. Agoti ${ }^{1}$, Lynette I. Ochola-Oyier ${ }^{1}$, Mark Otiende ${ }^{1}$, Christian Bottomley ${ }^{1}$, Amek Nyaguara ${ }^{1}$, Sophie Uyoga ${ }^{1}$, Katherine Gallagher ${ }^{1}$, Eunice W. Kagucia ${ }^{1}$, Dickens Onyango ${ }^{7}$, Benjamin Tsofa ${ }^{1}$, Joseph Mwangangi ${ }^{1}$, Eric Maitha ${ }^{8}$, Edwine Barasa $^{9,10}$, Philip Bejon ${ }^{1,10}$, George M. Warimwe ${ }^{1,10 \pm}$, J Anthony G Scott ${ }^{1,2 \pm}$, Ambrose Agweyu ${ }^{1 \pm}$

\section{Author Affiliations}

${ }^{1}$ KEMRI-Wellcome Trust Research Programme, Kilifi, Kenya

${ }^{2}$ London School of Hygiene and Tropical Medicine, UK

${ }^{3}$ Kenya Medical Research Institute Centre for Global Health Research, Kisumu, Kenya

${ }^{4}$ African Population and Health Research Center, Nairobi, Kenya

${ }^{5}$ Ministry of Health, Nairobi, Kenya

${ }^{6}$ Presidential Policy and Strategy Unit, The Presidency, Government of Kenya

${ }^{7}$ Department of Health, Kisumu County, Kenya

${ }^{8}$ Department of Health, Kilifi County, Kenya

${ }^{9}$ Health Economics Research Unit, KEMRI-Wellcome Trust Research Programme, Nairobi, Kenya

${ }^{10}$ Centre for Tropical Medicine and Global Health, Nuffield Department of Medicine, Oxford University, UK 


\section{Supplementary Appendix}

Table S1: Sex-stratified seroprevalence by HDSS site and study period

\begin{tabular}{|c|c|c|c|c|c|c|c|c|c|c|c|c|c|c|}
\hline \multirow[b]{3}{*}{ Period } & \multirow[b]{3}{*}{ Sex } & \multicolumn{12}{|c|}{ HDSS Site } & \\
\hline & & \multicolumn{4}{|c|}{ Kisumu } & \multicolumn{4}{|c|}{ Nairobi } & \multicolumn{4}{|c|}{ Kilifi } & \\
\hline & & $\mathrm{N}$ & $\begin{array}{l}\text { Sero } \\
+V E\end{array}$ & $\begin{array}{l}\text { Classical } \\
\text { adjustment }^{ \pm}\end{array}$ & $\begin{array}{l}\text { Bayesian } \\
\text { adjustment }\end{array}$ & $\mathrm{N}$ & $\begin{array}{l}\text { Sero } \\
+V E\end{array}$ & $\begin{array}{l}\text { Classical } \\
\text { adjustment }^{ \pm}\end{array}$ & $\begin{array}{l}\text { Bayesian } \\
\text { adjustment }\end{array}$ & $\mathrm{N}$ & $\begin{array}{l}\text { Sero } \\
+ \text { VE }\end{array}$ & $\begin{array}{l}\text { Classical } \\
\text { adjustment }^{ \pm}\end{array}$ & $\begin{array}{l}\text { Bayesian } \\
\text { adjustment }^{\S}\end{array}$ & 훙으. \\
\hline \multirow{2}{*}{01 Dec 20- 31 Dec 20} & Female & - & - & - & - & - & - & - & - & 96 & 18 & $11.2(7.7-14.6)$ & $17.0(9.8-25.7)$ & \\
\hline & Male & - & - & - & - & - & - & - & - & 66 & 9 & $13.1(4.1-22.1)$ & $11.6(4.7-20.7)$ & \\
\hline 01 Jan 21- 31 Jan 21 & Male & - & - & - & - & 50 & 16 & $27.0(23.7-30.4)$ & $32.9(19.6-48)$ & 52 & 13 & $17.6(12.1-23.1)$ & $25.8(14.3-39.4)$ & \\
\hline \multirow{2}{*}{01 Feb 21-28 Feb 21} & Female & 117 & 37 & $39.5(32.6-46.4)$ & $34.8(25.3-45.1)$ & 64 & 21 & $36.6(33.8-39.5)$ & $35.2(23-48.6)$ & 140 & 21 & $16.0(12.3-19.7)$ & $15.1(9.1-22.2)$ & 兽. \\
\hline & Male & 97 & 32 & 34.0 (28.3-39.8) & $37.4(26.4-49.3)$ & 80 & 27 & $25.2(20.7-29.8)$ & $36.5(25.2-48.8)$ & 99 & 20 & $21.0(16.3-25.6)$ & $20.7(12.6-29.7)$ & $\stackrel{\bar{D}}{=}$ \\
\hline \multirow{2}{*}{01 Mar 21-31 Mar 21} & Female & 123 & 47 & 35.9 (29.6-42.3) & $40.9(30.8-51.1)$ & 78 & 38 & $57.2(50.5-63.9)$ & $52.6(39.9-65.5)$ & 96 & 27 & $26.3(22.7-29.9)$ & $28.6(18.7-39.2)$ & 응 \\
\hline & Male & 95 & 34 & $32.2(24.9-39.4)$ & $38.8(27.9-50.2)$ & 108 & 39 & $45.2(40.3-50.0)$ & $42.2(31.2-54.0)$ & 101 & 20 & $18.5(12.6-24.4)$ & $20.2(12.6-29.3)$ & \\
\hline 01 Apr 21-30 Apr 21 & Male & 98 & 30 & $38.9(35.1-42.8)$ & $31.2(21.5-41.9)$ & 155 & 63 & $42.3(36.3-48.3)$ & $42.4(33.2-52.2)$ & 79 & 19 & $29.5(23.4-35.6)$ & $25.7(16.0-36.6)$ & \\
\hline \multirow{2}{*}{01 May 21-31 May 21} & Female & 114 & 48 & $45.1(37.1-53.0)$ & $45.4(35.4-55.8)$ & 56 & 30 & $44.3(38.5-50.2)$ & $56.6(41.6-71.5)$ & - & - & - & - & \\
\hline & Male & 103 & 37 & $45.3(39.8-50.8)$ & $38.3(28.2-49.3)$ & 57 & 24 & $49.7(44.6-54.9)$ & $44.7(30.9-59.4)$ & - & - & - & - & $=$ \\
\hline \multicolumn{14}{|c|}{${ }^{ \pm}$Kilifi HDSS population as at 18 Feb 2021 was used as the standard population. Prevalence estimates were adjusted for performance characteristics of assay used as described in methods section. } & 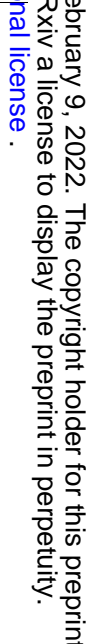 \\
\hline
\end{tabular}


medRxiv preprint doi: https://doi.org/10.1101/2022.02.07.22270012; this version posted February 9, 2022. The copyright holder for this preprint (which was not certified by peer review) is the author/funder, who has granted medRxiv a license to display the preprint in perpetuity. It is made available under a CC-BY 4.0 International license.

\section{Supplementary Appendix}

Table S2: Age and Sex-stratified seroprevalence by HDSS site for entire study period

\section{Entire study period}

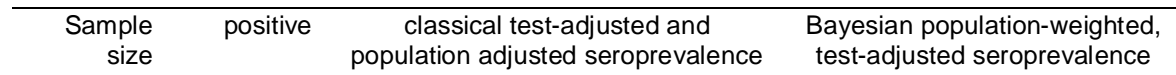

\begin{tabular}{|c|c|c|c|c|}
\hline \multicolumn{5}{|l|}{ Kisumu } \\
\hline Overall & 853 & 308 & $39.0(34.8-43.1)$ & $38.1(34.1-42.4)$ \\
\hline \multicolumn{5}{|l|}{ Sex } \\
\hline Female & 460 & 175 & $40.0(35.0-45.1)$ & $40.1(34.8-45.5)$ \\
\hline Male & 393 & 133 & $36.5(31.2-41.8)$ & $36.1(30.7-41.8)$ \\
\hline \multicolumn{5}{|c|}{ Age category (years) } \\
\hline $0-9$ & 199 & 43 & $25.6(18.3-32.9)$ & $25.5(19-32.8)$ \\
\hline $10-19$ & 150 & 53 & $37.4(29.1-45.7)$ & $38.3(30.6-46.3)$ \\
\hline $20-29$ & 102 & 42 & $44.4(34.2-54.5)$ & $42.9(33.9-52.5)$ \\
\hline $30-39$ & 101 & 46 & $48.9(37.3-60.5)$ & $45.9(36.5-55.9)$ \\
\hline $40-49$ & 100 & 38 & $42.7(31.2-54.1)$ & 39.7 (30.8-49.3) \\
\hline $50-59$ & 101 & 46 & $50.0(39.9-60.1)$ & $46.1(36.7-56.3)$ \\
\hline $60-69$ & 79 & 33 & $42.1(30.8-53.4)$ & $43.2(33.3-54)$ \\
\hline $70-79$ & 15 & 5 & $30.8(16.2-45.4)$ & $38.5(23.5-54.9)$ \\
\hline $80+$ & 6 & 2 & $25.3(25.3-25.3)$ & $39.9(22.6-58.7)$ \\
\hline$<15$ (children) & 299 & 79 & $29.8(23.9-35.7)$ & $28.6(23.1-34.6)$ \\
\hline $15+$ (adults) & 554 & 229 & $44.2(38.7-49.8)$ & $43.6(38.8-48.6)$ \\
\hline \multicolumn{5}{|l|}{ Nairobi } \\
\hline Overall & 850 & 322 & $39.6(35.2-44.0)$ & $40.4(36.0-45.0)$ \\
\hline \multicolumn{5}{|l|}{ Sex } \\
\hline Female & 400 & 153 & $37.3(31.7-42.9)$ & $40.0(34.4-45.9)$ \\
\hline Male & 450 & 169 & $41.3(35.9-46.7)$ & $40.7(35.1-46.5)$ \\
\hline \multicolumn{5}{|c|}{ Age category (years) } \\
\hline $0-9$ & 198 & 35 & $23.7(15.9-31.4)$ & $20.6(14.7-27.3)$ \\
\hline $10-19$ & 154 & 70 & $50.6(41.0-60.2)$ & $48.3(39.8-57.2)$ \\
\hline $20-29$ & 100 & 32 & $34.0(23.5-44.6)$ & $35.5(26.2-45.5)$ \\
\hline $30-39$ & 98 & 45 & $45.4(35.2-55.6)$ & $48.5(38.5-58.9)$ \\
\hline $40-49$ & 98 & 48 & $54.1(42.9-65.4)$ & $51.4(41.1-61.8)$ \\
\hline $50-59$ & 101 & 45 & $45.9(35.4-56.5)$ & $47.3(37.5-57.7)$ \\
\hline $60-69$ & 75 & 32 & $43.8(30.6-57.0)$ & $45.4(34.3-57.2)$ \\
\hline $70-79$ & 20 & 10 & $38.5(21.1-55.8)$ & $49.7(32.1-68.6)$ \\
\hline $80+$ & 6 & 5 & $82.5(82.5-82.5)$ & $57.1(33.9-83)$ \\
\hline$<15$ (children) & 299 & 73 & $28.5(22.3-34.7)$ & $28.3(22.9-33.9)$ \\
\hline $15+$ (adults) & 551 & 249 & $44.0(38.4-49.6)$ & $47.6(42.6-52.8)$ \\
\hline \multicolumn{5}{|l|}{ Kilifi } \\
\hline Overall & 856 & 173 & $20.0(17.0-23.0)$ & $19.8(16.8-23.1)$ \\
\hline
\end{tabular}


medRxiv preprint doi: https://doi.org/10.1101/2022.02.07.22270012; this version posted February 9, 2022. The copyright holder for this preprint (which was not certified by peer review) is the author/funder, who has granted medRxiv a license to display the preprint in perpetuity. It is made available under a CC-BY 4.0 International license.

\section{Supplementary Appendix}

Entire study period

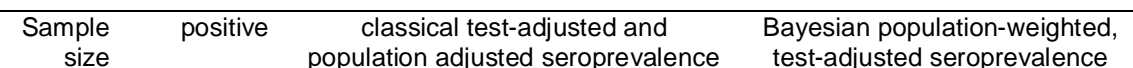

Sex

Female

459

92

$19.4(15.3-23.5)$

19.2 (15.3-23.4)

Male

397

81

20.8 (16.6-24.9)

$20.5(16.3-25.0)$

Age category (years)

0-9

197

16

8.4 (3.9-12.9)

$10.2(5.8-15.4)$

10-19

153

20-29

101

$21.9(14.7-29.1)$

$21.3(15.1-28.4)$

30-39

102

23.2 (14.9-31.6)

22.6 (15.1-31.3)

40-49

101

32.0 (22.4-41.6)

30.3 (21.8-39.8)

50-59

101

28.5 (19.4-37.6)

27.1 (18.9-36.4)

60-69

66

24.1 (14.8-33.5)

$22.6(15.2-31.1)$

70-79

27

$14.3(6.7-22.0)$

18.8 (10.6-28.3)

$80+$

8

41.1 (28.1-54.1)

31.4 (18.2-48.3)

10

$34.1(0-70.8)$

27.6 (12.6-50.2)

$<15$ (children)

295

35

12.3 (8.2-16.5)

12.5 (8.6-17.1)

15+ (adults)

561

138

$26.0(21.8-30.2)$

$25.5(21.5-29.7)$ 
medRxiv preprint doi: https://doi.org/10.1101/2022.02.07.22270012; this version posted February 9, 2022. The copyright holder for this preprint (which was not certified by peer review) is the author/funder, who has granted medRxiv a license to display the preprint in perpetuity. It is made available under a CC-BY 4.0 International license.

\section{Supplementary Appendix}

Figure S1: Location of study sites within Kenya

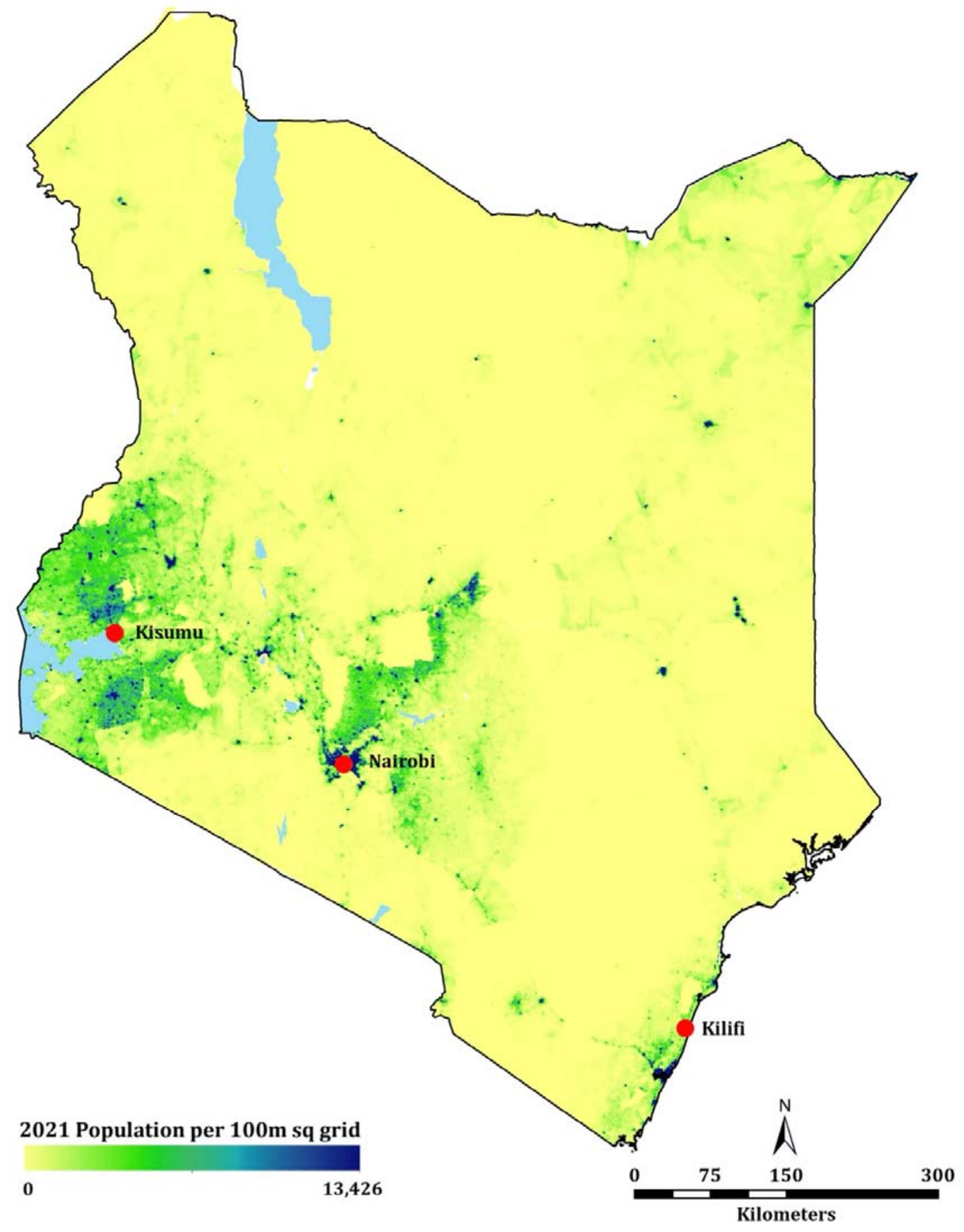

